The impact of plant density on the seed yield and the spring field pea's yield component

Utjecaj gustoće sjetve na prinos zrna i komponente prinosa jaroga stočnog graška

Krizmanić, G., Tucak, M., Brkić, A., Marković, M., Jovanović, V.S., Beraković, I., Čupić, T.

Poljoprivreda/Agriculture

ISSN: $1848-8080$ (Online)

ISSN: 1330-7142 (Print)

http://dx.doi.org/10.18047/poljo.26.1.4

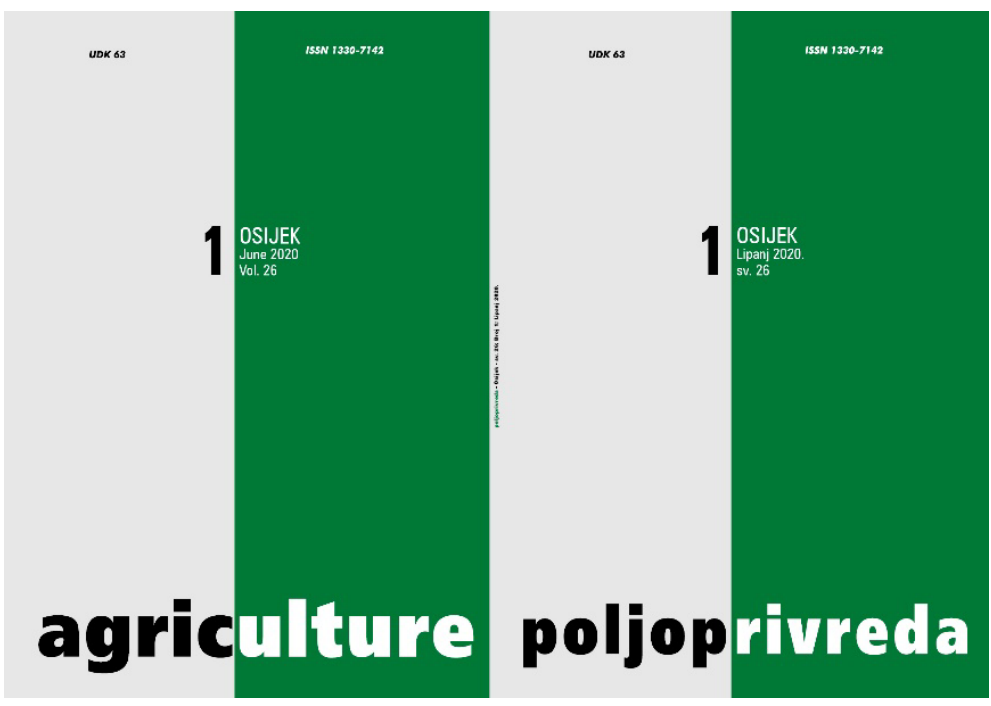

Fakultet agrobiotehničkih znanosti Osijek, Poljoprivredni institut Osijek

Faculty of Agrobiotechnical Sciences Osijek, Agricultural Institute Osijek 
ISSN 1330-7142

$U D K=631.53 .04: 633.35$

DOI: $10.18047 /$ poljo.26.1.4

\title{
THE IMPACT OF PLANT DENSITY ON THE SEED YIELD AND THE SPRING FIELD PEA'S YIELD COMPONENT
}

Krizmanić, G., ${ }^{(1)}$ Tucak, M., ${ }^{(1)}$ Brkić, A., (1) Marković, M., ${ }^{(2)}$ Jovanović, V. S., (3) Beraković, I., ${ }^{(1)}$ Čupić, T. ${ }^{(1)}$

Original scientific paper

Izvorni znanstveni članak

\begin{abstract}
SUMMARY
The spring field pea is one of the most important coarse legumes. This study was carried out to investigate the response of a spring field pea variety to three plant densities (50, 100, and 150 plant $\mathrm{m}^{-2}$ ) during the 2017 and 2019 growing seasons in eastern Croatia. The field study was set up as a Randomized Complete Block Design (RCBD) in four replications. The results have demonstrated a significant effect of the plant densities and the growing seasons on the seed yield and on the following yield components: plant height and the number of pods/plant. The effect of plant densities on the number of seeds/pod and the thousand-seed weight was not significant. As for a growing season, the highest seed yield, plant height, the number of pods/plant were obtained in the second growing season. Furthermore, a maximum seed yield was recorded at the 150-plant $m^{-2}$ plant density. This study has demonstrated that planting the spring field pea at different plant densities significantly modifies the spring field pea yield, plant height and number of pods/plant.
\end{abstract}

Keywords: spring field pea, plant densities, seed yield, yield components

\section{INTRODUCTION}

Among the grain legume crops, the spring field pea is one of the most important animal feeds in Croatia. The grain legumes, such as the field pea, are the important sources of proteins, carbohydrates, vitamins and minerals. According to Gatel and Grosjean (1990), Popović et al. (2015), and Bhat et al. (2013), the chemical analyses of the field pea grain compounds demonstrate a high content and good protein quality, within a range from $20-30 \%$. Also, the authors claim that the amino acid composition of soybean and cereal proteins have the same or very similar nutritional values as those of the legumes. Furthermore, Rapčan et al. (2010) and Marohnić (2006) have quoted some of the advantages of pea over the soybean (i.e., a simpler production, simpler grain storage, which does not contain oils, and a direct consumption without any preliminary treatment). Because of its relatively high content of crude protein and starch, a legume grain is a valuable food for any kind of livestock. Furthermore, this crop also plays a significant role in the soil fertility restoration as a suitable crop that fixes atmospheric nitrogen and also serves as a rotational crop that plays a great role in controlling disease epidemics and weeds (Yucel, 2013; Hoorman et al., 2009). As indicated by Mohamed et al. (2006), the grain legumes can be considered a leading candidate for the protein supply to the poor areas of the world, especially in the areas in which there is a pressing need for a high energy and protein. In most pea-breeding programs, the selection process is focused on the development of high

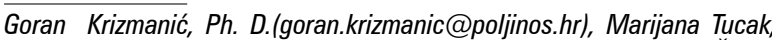
Ph. D., Andrija Brkić, Ph. D., Ivica Beraković, Ph. D., Tihomir Čupić, Ph. D. - Agricultural Institute Osijek, Južno predgrađe 17, 31000 Osijek, Croatia, (2) Monika Marković, Ph. D. - Josip Juraj Strossmayer University of Osijek, Faculty of Agrobiotechnical Sciences Osijek, Vladimira Preloga 1, 31000 Osijek, Croatia, (3) Snežana V. Jovanović, Ph. D. - Maize Research Institute, 11185 Zemun Polje,Belgrade, Slobodana Bajića 1, Serbia 
yielding and on the top-quality varieties for grain and/ or green forage production. In Croatia, the production of protein-rich grain is mainly associated with spring varieties. The seed yield is a complex trait determined by other yield components. The basic components of a field pea yield are the plant height, the number of pods/plant, seeds/pod, and the thousand-seed weight. Among many yield-limiting factors in the field pea production, a plant density and a planting method are the important ones (Bitew et al. 2015). Therefore, one of the main tasks in the grain legumes production is finding the optimum plant density, whereby the competition between the plants will not result in a significant yield reduction. The optimum plant population has a promising impact on the improvement of legume productivity (Sibhatu et al., 2016). According to Sibhatu et al. (2016) and Rajput et al. (1984), a wider row spacing (60 and $45 \mathrm{~cm}$ ) resulted in a significantly higher number of pods/plant, as compared to a $30-\mathrm{cm}$ row spacing. This is supported by Kakiuchi and Kobata (2004), who concluded that a lower plant density increased the number of pods/plant, and a higher plant density decreased the number of pods/plant. Ibrahim at al. (2019) and Parihar (1996) reported that there were no significant effects of cultivars, plant densities, and their interaction on the plant height and other studied traits (i.e., the number of branches/plant, the number of pods/plant, the number of seeds/pod, the number of seeds/plant, a biological yield, etc.). According to Yucel (2013), a seeding rate, plant density, and varieties are the important factors affecting the yield and the quality of grain legumes. The same authors claim that increasing a seeding rate may increase the competitive ability of crops. On the other hand, a crop profitability may or may not increase, owing to a high seed cost in pulses. This study's objective was to estimate the impact/effect of plant density on the seed yield and the yield components of the spring field pea variety Uran while identifying an optimal planting spacing.

\section{MATERIAL AND METHODS}

\section{Field experiment and data collection}

A field trial was conducted at the Agricultural Institute of Osijek's Research Station (45.32" N and $18^{\circ} 44^{\prime \prime} \mathrm{E}, 90-\mathrm{m}$ altitude) during the 2017 and 2019 growing seasons. The experimental site was a hydromeliorated hypogley (a silty clay, loamy soil) with the $\mathrm{pH}$ in $\mathrm{KCl}$ amounting to 6.6 , an organic matter content amounting to $2.55 \%$, with $26.4 \mathrm{mg} / 100 \mathrm{~g}$ of $\mathrm{P}_{2} \mathrm{O}_{5}, 29.7$ $\mathrm{mg} / 100 \mathrm{~g}$ of $\mathrm{K}_{2} \mathrm{O}$ and $1.25 \%$ of $\mathrm{CaCO}_{3}$, a water holding capacity amounting to $36.6 \%$, and an air capacity amounting to $5.3 \%$ in a $0-32 \mathrm{~cm}$ soil profile (Marković et al., 2015). (The plant density treatments were as follows: 50 plant $\mathrm{m}^{-2}, 100$ plant $\mathrm{m}^{-2}$, and 150 plant $\mathrm{m}^{-2}$ ). The treatments were arranged in a randomized completed block design (RCBD) in four replicates. The size of the experimental plots amounted to $2 \times 2.8 \mathrm{~m}$. The spacing between the blocks and plots amounted to 1 and $0.5 \mathrm{~m}$, respectively. The standard agrotechnical measures for spring field pea cultivation were applied in both growing seasons: an autumnal tillage at a $40-\mathrm{cm}$ depth, fertilization (autumnal season) with $250 \mathrm{~kg} \mathrm{ha}^{-1}$ of mineral fertilizer (N:P:K 7:20:30 formulations), and 100 $\mathrm{kg} \mathrm{ha}^{-1}$ of Urea fertilizer ( $46 \%$ source of N). The spring field pea was sown on March 27, 2017 and on March 30,2019 . A local variety of Uran was used as a test crop. Other crop management practices included weeding (a chemical spraying applied uniformly to all plots) three weeks subsequent to the planting. All plants were hand-harvested at the end of June during both growing seasons. The following measurements were recorded from ten randomly selected plants from the each plot's middle row: a plant height $(\mathrm{PH}-\mathrm{cm})$, a number of pods/ plant (NPPP), a number of seeds/pod (NSPP), thousandseed weight (TSW - gram) and seed yield (SY - $\mathrm{t} \mathrm{ha}^{-1}$ ). After harvest, thousand-seed weight was determined by mixing the whole sample and then 100 seeds were randomly counted, weighted, and multiplied by 10 . As for seed yield, four middle rows of each plot were harvested, weighed, and converted into $\mathrm{tha}^{-1}$.

\section{Statistical analysis}

The collected data for each tested variable were subjected to a variance analysis (ANOVA). The comparisons between the means were performed using the least significant differences (LSD) at a 5-percent probability level (Gomez and Gomez, 1984). A correlation coefficient was used to determine the relationships among the tested variables. The statistical analyses were performed using the (STAR) - Statistical Tool for Agricultural Research, Version 2.0.1.

\section{Climatic conditions}

With its climatic conditions, the experimental site is representative of the southern part of the Pannonian region, which is situated in south-eastern Europe. The meteorological data were obtained from the National Meteorological Station in 0sijek, located $1.5 \mathrm{~km}$ away from the Experimental Station. A rainfall-related longterm average (LTA) amounting to 30 years amounts to $683 \mathrm{~mm}$ for the 0sijek region, while the average air temperature amounts to $11.3^{\circ} \mathrm{C}$. According to Lang's climate classification, the study location's climate is semi-humid. The mean air temperatures and the precipitation amount during the study period (2017 and 2019) are shown in Figs. 1 and 2. The average air temperature during the 2019 growing season was $6.1^{\circ} \mathrm{C}$ higher when compared to that of 2017. The amount of precipitation during both growing seasons was unequally distributed. During 2017, the amount of precipitation $(212.9 \mathrm{~mm}$, Fig. 1) was 38\% lower than that of the year 2019 (340.6 mm, Fig. 2). 


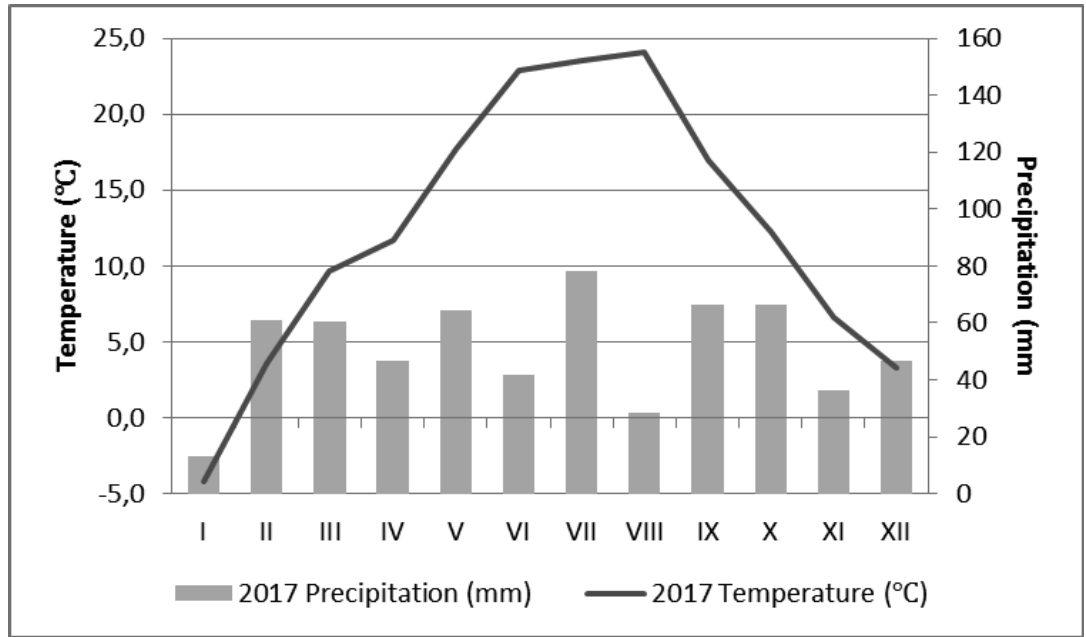

Figure 1. The mean monthly air temperatures $\left({ }^{\circ} \mathrm{C}\right)$ and total monthly precipitation $(\mathrm{mm})$ the 2017 season Slika 1. Prosječne mjesečne temperature zraka $\left({ }^{\circ} \mathrm{C}\right)$ i ukupne mjesečne količine oborina (mm) za 2017. godinu

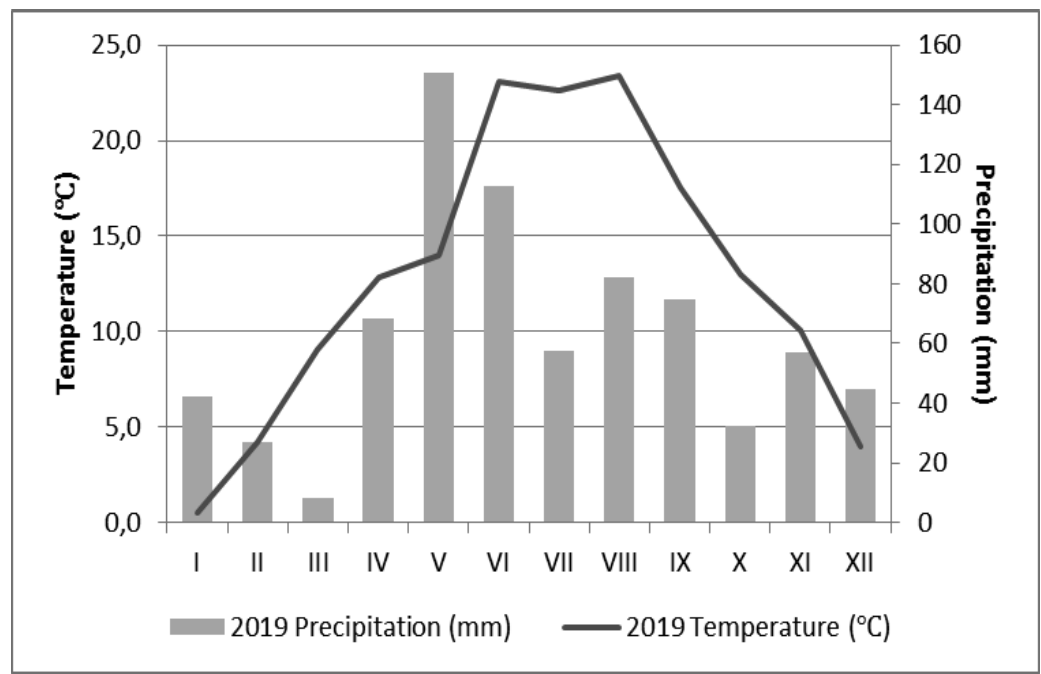

Figure. 2. The mean monthly air temperatures $\left({ }^{\circ} \mathrm{C}\right)$ and total monthly precipitation $(\mathbf{m m})$ in the $\mathbf{2 0 1 9}$ season Slika 2. Prosječne mjesečne temperature zraka $\left({ }^{\circ} \mathrm{C}\right)$ i ukupne mjesečne količine oborina $(\mathrm{mm})$ za 2019. godinu

\section{RESULTS AND DISCUSSION}

The ANOVA results have manifested a significant impact of planting densities on the seed yield, the number of pods/plant, and plant height. The averages across a plant density treatment for the plant height ranged from $53.9 \mathrm{~cm} \mathrm{(2017)} \mathrm{to} 87.6 \mathrm{~cm}$ (2019). Averaged across a growing season, the plant height ranged from 67.1 (50 plants $\mathrm{m}^{-2}$ ) to $73.2 \mathrm{~cm}$ (150 plants $\mathrm{m}^{-2}$ ) (Table 1). Increasing the plant density, i.e., decreasing a within-row sowing distance, induced a higher plant growth, which can be explained by a plant competition in higher densities-due to a limited vegetation area, the light requirements are higher and the plants intensify their growth. The similar results were reported by Yucel (2013), who found that the plant height increases as a planting density increases, from 300,000 plants ha $^{-1}$ to 500,000 plants ha ${ }^{-1}$. Sibhatu et al. (2016) reported that the greatest plant might most probably be due to the availability of free access to the environmental resources (water, nutrients, and light) for the plants in a wider spacing. However, the contrasted findings were presented by Inanç and Yıldırım (2007), who indicated that the denser pea plant population have increased a plant height due to a competition among the plants. The impact of seed density on the number of pods/plant is presented in Table 1. The averages across a plant density treatment and the number of pods/plant ranged from 5.1 (2017) to 7.4 (2019). In both growing seasons, the plant density of 150 plants $\mathrm{m}^{-2}$ significantly $(p<0.05)$ decreased the number of pods/plant $(2017=4.3 ; 2019$ $=6.5$ ).

The averages across the years (Table 1 ) for the number of pods/plant ranged from 5.4 (150 plants $\mathrm{m}^{-2}$ ) to $6.8\left(50\right.$ plants $\left.\mathrm{m}^{-2}\right)$. The increased number of pods/ 
plant in a treatment with the lower plant densities occurred because the plants were growing stronger, and that they developed more secondary branches in favorable conditions, as a larger growing area provides less competition from the neighboring plants and a greater insolation. Our study results are consistent with the study conducted by Bitew et al. (2014), who reported that a reduction in the plant population (wider intra- and inter-row spacing) significantly increased the number of pods/plant. This statement is also supported by Sharma (2002), who found that a reduction in the plant population significantly increases the number of pods/plant. No significant differences were found for the number of seeds/pod (Table 1) and thousand-seed weight (Table 2).

Moreover, a number of seeds/pod and thousandseed weight were relatively constant across the plant densities. Also, Sibhatu et al. (2016) have reported that number of seeds/pod of field pea was not significantly influenced by the plant spacing. Rasaei et al. (2012) reported that the influence of plant density on the number of pea seeds/pod was insignificant. Bitew et al. (2014) also demonstrated that the thousand-seed weight was not significantly affected by an intra- and inter-row spacing, and there was no difference in a thousand-seed weight between both field pea varieties. Similarly, Shirtliffe and Johnston (2002) noticed that there were no significant differences in the row spacing for a thousand-seed weight. The statistical analysis of field pea yields revealed that there was a significant $(p<0.05)$ difference between the plant density treatment in both growing seasons (Table 2). Averaged across a plant density treatment, the pea seed yield ranged from 4.4 t ha $^{-1}$ (2017) to 4.7 t ha- $^{-1}$ (2019). In both growing seasons, the pea seed yield was higher as the plant density was getting higher. Averaged across a growing season, the pea yield ranged from $2.71 \mathrm{tha}^{-1}\left(50\right.$ plants $\left.\mathrm{m}^{-2}\right)$ to $6.01 \mathrm{t} \mathrm{ha}^{-1}$ (150 plants $\left.\mathrm{m}^{-2}\right)$. In the first year of the study, the pea seed yield was significantly lower in 50 plant $\mathrm{m}^{-2}$ density treatment $(\mathrm{p}<0.05)$ when compared to a 100- and 150-plant $\mathrm{m}^{-2}$ treatment (Table 2), while there were no significant differences among a 100 - and a 150plant $\mathrm{m}^{-2}$ treatment. Although the climatic conditions have not been analyzed in this study (e.g., the influence of precipitation and temperatures on the yield and yield components), the environmental effects on the seed yield and yield component variations should still not be neglected. The higher amount of precipitation during the 2019 growing season (Figs. 1 and 2) resulted in the differences in the seed yield and yield components as well (Tables 1 and 2). Rapčan et al. (2010) reported that the air temperature, with a sufficient amount and favorable distribution of precipitation during the growing season, had a special significance the obtainment of a high grain yield, particularly during the pea flowering.

The highest variation coefficient among the analyzed variables was found for the seed yield ( $\mathrm{CV}=39.41 \%$ and $\mathrm{CV}=37.47 \%$ ) in both growing seasons (Table 2), which emphasizes the high variability of the seed yield-a phenotypic expression is considerably affected by the environmental effects, i.e., a genotype was affected by an environmental interaction (Tadesse et al., 2017; Iglesias-García et al., 2017). In our study, the highest pea seed yield in both growing seasons was obtained in a density treatment concerning 150 plants $\mathrm{m}^{-2}$ (Table 2). The yield was by $19 \%$ higher than that for the 100 -plant $\mathrm{m}^{-2}$ densities. This result was contrary to the research conducted by Sibhatu et al. (2016), who reported that the lowest plant density produced the highest seed yield, and that the lowest seed yield was produced in the highest density. Also, the same authors claim that the lowest seed yield could be achieved due to an extremely wider spacing at which the required population density $\mathrm{ha}^{-1}$ could not be accommodated, and this in turn resulted in the production of a low seed yield because of the minimum population density. The other authors figured different results. Türk et al. (2011) reported that the dry pea seed yield increased with an increasing plant population density, from 30 to 80 plant $\mathrm{m}^{-2}$. Yucel (2013) reported that the dry pea seed yield increased with an increasing

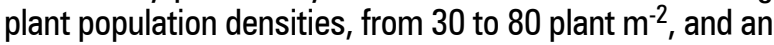
optimum plant population for maximizing the seed yield from 60 to 70 plant $\mathrm{m}^{-2}$ for the dry pea. The similar results were presented by Rasaei et al. (2012). The authors state that the seed field peas yield was significantly affected by the population density.

Table 1. The effect of plant densities on the mean values of plant height, number of pods/plant, and the number of seeds/pod of the Uran varieties

Tablica 1. Utjecaj gustoće sjetve na srednje vrijednosti visine biljke, broj mahuna po biljci i broj zrna po mahuni sorte Ura

\begin{tabular}{|l|c|c|c|c|c|c|c|c|c|c|}
\hline \multirow{2}{*}{$\begin{array}{c}\text { Treatments } \\
\text { Tretmani }\end{array}$} & \multicolumn{3}{|c|}{$\begin{array}{c}\text { Plant height (cm) } \\
\text { Visina biljke (cm) }\end{array}$} & \multicolumn{3}{c|}{$\begin{array}{c}\text { Number of pods/plant } \\
\text { Broj mahuna po biljci }\end{array}$} & \multicolumn{4}{c|}{$\begin{array}{c}\text { Number of seeds/pod } \\
\text { Broj zrna po mahuni }\end{array}$} \\
\cline { 2 - 14 } & 2017 & 2019 & Mean & 2017 & 2019 & Mean & 2017 & 2019 & Mean \\
\hline 50 & $50.5 \mathrm{~b}$ & 83.7 & $67.1 \mathrm{~b}$ & $5.9 \mathrm{a}$ & $7.7 \mathrm{ab}$ & $6.8 \mathrm{a}$ & 3.9 & 3.8 & 3.8 \\
\hline 100 & $55.2 \mathrm{a}$ & 88.7 & $71.9 \mathrm{a}$ & $5.2 \mathrm{a}$ & $8.1 \mathrm{a}$ & $6.6 \mathrm{a}$ & 3.8 & 3.5 & 3.7 \\
\hline 150 & $56.0 \mathrm{a}$ & 90.5 & $73.2 \mathrm{a}$ & $4.3 \mathrm{~b}$ & $6.5 \mathrm{~b}$ & $5.4 \mathrm{~b}$ & 3.7 & 3.6 & 3.7 \\
\hline Mean/Prosjek & 53.9 & 87.6 & 70.7 & 5.1 & 7.4 & 6.3 & 3.8 & 3.6 & 3.7 \\
\hline $\mathrm{CV} \mathrm{( \% )}$ & 13.30 & 15.44 & 15.3 & 33.33 & 36.11 & 35.83 & 20.97 & 26.04 & 23.53 \\
\hline $\mathrm{LSD}_{0.05}$ & 3.17 & n. s. & 4.44 & 0.75 & 1.18 & 0.92 & n. s. & n. s. & n. s \\
\hline
\end{tabular}

$\mathrm{LSD}_{0.05}$ - least significant difference at $\mathrm{p}<0.05$ respectively - značajna razlika na razini značajnosti $p<0,05 ; n$. $s$. - not significant / nema značajnosti 
Table 2. The effect of plant densities on the mean values of thousand-seed weight $(\mathrm{g})$ and the seed yield $\left(\mathrm{kg} \mathrm{ha}^{-1}\right)$ of Uran varieties

Tablica 2. Utjecaj gustoće sjetve na srednje vrijednosti mase 1000 zrna i prinosa zrna sorte Uran

\begin{tabular}{|c|c|c|c|c|c|c|}
\hline \multirow{2}{*}{$\begin{array}{l}\text { Treatments } \\
\text { Tretmani }\end{array}$} & \multicolumn{3}{|c|}{$\begin{array}{c}\text { Thousand-seed weight }(\mathrm{g}) \\
\text { Masa } 1000 \text { zrna }(\mathrm{g})\end{array}$} & \multicolumn{3}{|c|}{$\begin{array}{l}\text { Seed yield }\left(t h^{-1}\right) \\
\text { Prinos zrna }\left(\left(t h a^{-1}\right)\right.\end{array}$} \\
\hline & 2017 & 2019 & Mean & 2017 & 2019 & Mean \\
\hline \multicolumn{7}{|c|}{ Plant densities, $\mathrm{m}^{2}-$ Gustoća sjetve, $m^{2}$} \\
\hline 50 & 234.3 & 186.8 & 210.5 & $2.67 \mathrm{~b}$ & $2.76 c$ & $2.71 \mathrm{c}$ \\
\hline 100 & 233.5 & 174.8 & 204.2 & $4.72 \mathrm{a}$ & $5.13 b$ & $4.93 b$ \\
\hline 150 & 227.0 & 177.1 & 202.1 & $5.80 \mathrm{a}$ & $6.23 a$ & $6.01 \mathrm{a}$ \\
\hline Mean & 231.6 & 179.6 & 205.6 & 4.40 & 4.70 & 4.55 \\
\hline CV $(\%)$ & 12.22 & 18.85 & 15.18 & 39.41 & 37.47 & 38.44 \\
\hline $\mathrm{LSD}_{0.05}$ & n. s. & n. s. & n. s & 1.08 & 1.05 & 0.75 \\
\hline
\end{tabular}

$\mathrm{LSD}_{0.05}$ - least significant difference at $\mathrm{p}<0.05$ respectively; - značajna razlika na razini značajnosti $p<0,05$ / n.s. - not significant / nema značajnosti

A correlation analysis for the yield and yield components is presented in Table 3. According to Pearson's correlation analysis, a seed yield was significantly and positively correlated to all the tested yield components. As presented in Table 3, the number of pods/plant $\left(r=0.754^{* *}\right)$ and the number of seeds/pod $\left(r=0.494^{* *}\right)$ demonstrated the strongest positive correlations to the seed yield in both growing seasons. Furthermore, a thousand-seed weight $\left(r=0.335^{* *}\right)$ and plant height $\left(r=0.284^{* *}\right)$ were also positively correlated to the seed yield $(p<0.01)$, while the number of pods/plant was negatively correlated to the thousand-seed weight $(r=-0.125)$ and the number of seeds/pod $(r=-0.008)$, although not significantly. These results are in agreement with Shirtliffe and Johnston (2002), who stated that a negative correlation between the thousand-seed weight and the number of pods/plant, as well as a significant and positive correlation between the seed yield and the number of seeds/pod, indicate that an increase in these traits in pea cultivar decreases the thousand-seed weight and increases the seed yield of the pea cultivar. The same results were presented by Ibrahim et al. (2019), who reported that the thousand-seed weight was negatively correlated to the number of pods/plant in both cultivars.

Table 3. Pearson's correlation between a seed yield and its components during the 2017 and 2019 growing seasons Tablica 3. Pearsonova korelacija između prinosa zrna i komponenti prinosa tijekom 2017. i 2019. godine

\begin{tabular}{|l|c|c|c|c|}
\hline & PH & NPPP & NSPP & TSW \\
\hline Seed yield & $0.284^{* *}$ & $0.754^{* *}$ & $0.494^{* *}$ & $0.335^{* *}$ \\
\hline Plant height & - & $0.519^{* *}$ & 0.055 & $-0.395^{* *}$ \\
\hline Number of pods/plant & & - & -0.008 & -0.125 \\
\hline Number of seeds/pod & & & - & $0.178^{* *}$ \\
\hline Thousand-seed weight & & & & - \\
\hline
\end{tabular}

${ }^{*}$ r-value is statistically significant at 0.01 probability levels, respectively

SY, PH, NPPP, NSPP, and TSW refer to the seed yield in $\mathrm{t} \mathrm{ha}{ }^{-2}$ plant height in $\mathrm{cm}$, the number of pods/plant, the number of seeds/pod and the thousandseed weight in grams, respectively

\section{CONCLUSION}

The plant densities have exerted a significant impact on the spring field pea yield and the following yield components: a plant height and the number of pods/plant. According to the study results, the seed yield and the plant height increased with the increase in plant density, while the number of pods/plant and the number of seeds/pod decreased with an increase in plant density. The 100 to 150 plant $\mathrm{m}^{-2}$ plant density may be more suitable for a pea grown in eastern Croatia. This study demonstrated that these factors (plant densities) significantly modify the spring field pea yield and the yield components.

\section{REFERENCES}

1. Bhat, T. A., Gupta, M., Ganai, M. A., Ahanger, R. A., \& Bhat, H. A. (2013). Yield, soil health and nutrient utilization of field pea (Pisum sativum L.) as affected by phosphorus and Biofertilizers under subtropical conditions of Jammu. International Journal of Modern Plant and Animal Science, 1(1), 1-8.

2. Bitew, Y., Asargew, F., \& Beshir, 0. (2014). Effect of plant spacing on the yield and yield component of Field Pea (Pisum sativum L.) at Adet, North Western Ethiopia. Agri Forest and Fish, 3(5), 368-373.

3. Bitew, Y., Asargew, F., \& Chakelie, G. (2015). Evaluation of intra and inter row spacing on the seed yield and yield 
component of Field pea (Pisum sativum L.). Journal de Afrikana, 2(2), 1-15.

4. Gatel, F., \& Grosjean, F. (1990). Composition and nutritive value of peas for pigs: a review of European results. Livestock Production Science, 26(3), 155-175.

5. Gomez, K. A., \& Gomez, A. A. (1984). Statistical procedures for agricultural research. John Wiley \& Sons.

6. Hoorman, J. J., Islam, R., \& Sundermeier, A. (2009). Sustainable crop rotations with cover crops. Ohio State University. http://ohioline. osu. edu/sag-fact/pdf/0009. pdf

7. Ibrahim, D. M., Mohamed, S. J., \& Ahmed, S. M. (2019). Effects of plant density on seed yield and it's components of two pea (Pisum sativum L.) cultivars under rainfed condition in Sulaimani province. Journal of Kerbala for Agricultural Sciences, 6(1), 36-48.

8. Iglesias-García, R., Prats, E., Flores, F., Amri, M., Mikić, A., \& Rubiales, D. (2017). Assessment of field pea (Pisum sativum L.) grain yield, aerial biomass and flowering date stability in Mediterranean environments. Crop and Pasture Science, 68(11), 915-923. https://doi.org/10.1071/CP16423

9. Inanç, S., \& Yıldırım, B. (2007, July). The Effect of Different Row Space Applications on the Yield and Yield Components in Pea (Pisum sativum L.). In Turkish VII. Field Crops Congress (pp. 25-27).

10. Kakiuchi, J., \& Kobata, T. (2004). Shading and thinning effects on seed and shoot dry matter increase in determinate soybean during the seed-filling period. Agronomy Journal, 96(2), 398-405. https://doi.org/10.2134/agronj2004.0398

11. Mohamed, S. S., Taha, F. S., \& Karlsson, E. N. (2006). Production of functional protein hydrolysates from Egyptian breeds of soybean and lupin seeds. African Journal of Biotechnology, 5(10).

12. Marković, M., Tadić, V., Josipović, M., Zebec, V., \& Filipović, V. (2015). Efficiency of maize irrigation scheduling in climate variability and extreme weather events in eastern Croatia. Journal of Water and Climate Change, 6(3), 586-595. https://doi.org/10.2166/wcc2015.042

13. Marohnić, I. (2006). Grašak - buduće glavno bjelančevinasto krmivo Europe. Krmiva: časopis o hranidbi životinja, proizvodnji i tehnologiji krme, 48(6), 363368.

14. Parihar, S. S. (1996). The effect of row and plant spacings on the growth and yield of chickpea. Indian Journal of Agronomy, 41(4), 604-607.

15. Popović, S., Tucak, M., Čupić, T., \& Krizmanić, G. (2015). The influence of precipitation on forage pea seed yields. Poljoprivreda, 21(2), 10-14. https://doi.org/10.18047/poljo.21.2.2. 10-14
16. Rajput, M. J., Tunio, S., Rajput, M. A., \& Rajput, F. K. (1984). Effect of row and plant spacings on yield and yield components in soybean. Pakistan Journal of Agricultural Research, 5(2), 83-87.

17. Rapčan, I., Bukvić, G., Grljušić, S., Teklić, T., \& Jurišić, M. (2010). Yield of green mass, grain and other yield components of field pea (Pisum sativum L.) in dependence of agroecological conditions and seed maturity. Mljekarstvo/Dairy, 60(2). 104-112.

18. Rasaei, A., Ghobadi, M. E., \& Ghobadi, M. (2012). Effect of supplemental irrigation and plant density on yield and yield components of peas (Pisum sativum L.) in Kermanshah region. African Journal of Agricultural Research, 7(15), 2353-2358. https://doi.org/10.5897/AJAR11.1559

19. Sharma, S. K. (2002). Effect of sowing time and spacing levels on seed production of pea cultivar Arkel. Seed Research, 30(1), 88-91.

20. Shirtliffe, S. J., \& Johnston, A. M. (2002). Yield-density relationships and optimum plant populations in two cultivars of solid-seeded dry bean (Phaseolus vulgaris L.) grown in Saskatchewan. Canadian Journal of Plant Science, 82(3), 521-529. https://doi.org/10.4141/P01-156

21. Sibhatu, B., Berhe, H., Gebrekorkos, G., \& Abera, K. (2016). Determination of planting spacing for improved yield and yield components of Dekoko (Pisum sativum var. abyssinicum) at Raya Valley, Northern Ethiopia. African Journal of Plant Science, 10(8), 157-161. https://doi.org/10.5897/AJPS2016.1428

22. Statistical Tool for Agricultural Research. Version 2.0.1 Copyright Internacional Rice Research Institute (RR) 2013-2020.

23. Tadasse, T., Sefera, G., Mulugeta, B., \& Tekaling, A. (2017). Interaction of field pea genotypes with environment for grain yield in the highland of Bale zone, Southeastern Ethiopia. https://doi.org/10.11648/j.plant.20170501.14

24. Türk, M., Albayrak, S., \& Yüksel, 0. (2011). Effect of seeding rate on the forage yields and quality in pea cultivars of differing leaf types. Turkish Journal of Field Crops, 16(2), 137-141.

25. Yucel, D. 0. (2013). Impact of plant density on yield and yield components of pea (Pisum sativum ssp sativum L.) cultivars. APRN Journal of Agricultural and Biological Science, 8(2), 169-174. 


\section{UTJECAJ GUSTOĆE SJETVE NA PRINOS ZRNA I KOMPONENTE PRINOSA JAROGA STOČNOG GRAŠKA}

\section{SAŽETAK}

Jari stočni grašak jedna je od najznačajnijih krupnozrnih mahunarki. Ovo je istraživanje provedeno kako bismo vidjeli reakciju utjecaja različitih gustoća sjetve na jari stočni grašak tijekom dvaju vegetacijskih ciklusa 2017. i 2019. godine u istočnome dijelu Republike Hrvatske. Pokus je postavljen po RCBD sustavu u četiri ponavljanja. Rezultati pokazuju značajan utjecaj gustoće sjetve i godina istraživanja na prinos zrna $i$ većinu komponenata prinosa: visinu biljke i broja mahuna po biljci, osim broja zrna po mahuni i mase tisuću zrna, gdje gustoća sjetve nije statistički značajno utjecala na razlike u vrijednostima istraživanih svojstava. Najveće vrijednosti prinosa zrna, visine biljke i broja mahuna po biljci ostvarene su u drugoj godini istraživanja. Najveći prinos zrna zabilježen je pri gustoći sjetve od 150 biljaka/m². Istraživanje pokazuje da različite gustoće sjetve značajno modificiraju/utječu na visinu prinosa zrna i komponente prinosa jaroga stočnog graška.

Ključne riječi: jari stočni grašak, gustoća sjetve, prinos zrna, komponente prinosa

(Received on March 24, 2020; accepted on May 22, 2020 - Primljeno 24. ožujka 2020.; prihvaćeno 22. svibnja 2020.) 